\title{
Abundance and distribution of gaseous ammonia and particulate ammonium at Delhi, India
}

\author{
S. Singh and U. C. Kulshrestha \\ School of Environmental Sciences Jawaharlal Nehru University, New Delhi 110067, India \\ Correspondence to: U. C. Kulshrestha (umeshkulshrestha@gmail.com) \\ Received: 30 September 2011 - Published in Biogeosciences Discuss.: 5 January 2012 \\ Revised: 1 November 2012 - Accepted: 16 November 2012 - Published: 7 December 2012
}

\begin{abstract}
This study reports abundance and distribution of gaseous $\mathrm{NH}_{3}$ and particulate $\mathrm{NH}_{4}^{+}$at Delhi. Gaseous $\mathrm{NH}_{3}$ and particulate $\mathrm{NH}_{4}^{+}$concentrations were measured during pre-monsoon, monsoon and post-monsoon seasons of the years 2010 and 2011. Average concentrations of gaseous $\mathrm{NH}_{3}$ during pre-monsoon, monsoon and post-monsoon seasons were recorded as $26.4,33.2$ and $32.5 \mu \mathrm{g} \mathrm{m}^{-3}$, respectively. Gaseous $\mathrm{NH}_{3}$ concentrations were the highest during monsoon, thought to be due to decay and decomposition of plants and other biogenic material under wet conditions, leading to increased $\mathrm{NH}_{3}$ emission. The results showed that particulate $\mathrm{NH}_{4}^{+}$was always lower than the gaseous $\mathrm{NH}_{3}$ during all the seasons. The concentrations of particulate $\mathrm{NH}_{4}^{+}$were recorded as $11.6,22.9$ and $8.5 \mu \mathrm{g} \mathrm{m}^{-3}$ during pre-monsoon, monsoon and post-monsoon seasons, respectively. The percent fraction of particulate $\mathrm{NH}_{4}^{+}$was noticed to be highest during the monsoon season, which is attributed to increased humidity levels favouring partitioning into the aerosol phase. On an average, $33.3 \%$ of total $\mathrm{N}-\mathrm{NH}_{\mathrm{x}}$ was present as particulate $\mathrm{NH}_{4}^{+}$. Higher concentrations of $\mathrm{NH}_{3}$ noticed during night time may be due to stable atmospheric conditions. The study highlighted that, as compared with rural sites, urban sites showed higher concentrations of gaseous $\mathrm{NH}_{3}$ in India, which may be due to higher population density, human activities and poor sanitation arrangements.
\end{abstract}

\section{Introduction}

Recently, atmospheric research has been focused on the nitrogen cycle in order to understand the role of nitrogen in the atmosphere, ocean and terrestrial ecosystems. Reactive nitrogen plays an important role in the atmosphere. Ammonia and ammonium $\left(\mathrm{NH}_{\mathrm{x}}\right)$ are important reactive nitrogen species in the atmosphere. Atmospheric ammonia has become an environmental concern because of two main reasons; firstly, because of its neutralizing nature and secondly, due to ecological consequences of its deposition on sensitive ecosystems, causing eutrophication (Sutton et al., 1998, 2009). Ammonia catalyzes the atmospheric reaction, i.e. oxidation of $\mathrm{SO}_{2}$ in $\mathrm{SO}_{3}$ and reacts rapidly with $\mathrm{H}_{2} \mathrm{SO}_{4}, \mathrm{HNO}_{3}$. Neutralization results in submicron-sized $\mathrm{NH}_{4}$ salts, i.e. $\left(\mathrm{NH}_{4}\right)_{2} \mathrm{SO}_{4}$, $\mathrm{NH}_{4} \mathrm{HSO}_{4}$ and $\mathrm{NH}_{4} \mathrm{NO}_{3}$ etc., which play an important role in radiative forcing. In spite of its initial neutralizing effect on atmospheric chemistry, the deposition of $\mathrm{NH}_{\mathrm{x}}$ leads to acidification of the soil similar to the acidic effect of $\mathrm{SO}_{2}$ and $\mathrm{NO}_{\mathrm{x}}$ because of its oxidation in the soil to form nitrates (Jongebreur and Voorburg, 1992). Deposition of $\mathrm{NH}_{\mathrm{x}}$ from the atmosphere provides an excess $\mathrm{N}$ input to the ecosystem.

Sources of atmospheric $\mathrm{NH}_{3}$ vary from region to region, Europe being the highest emitter, followed by the Indian subcontinent and China. Major sources of atmospheric $\mathrm{NH}_{3}$ include domestic animals, biomass burning, oceans, human population and pets, use of synthetic $\mathrm{N}$ fertilizers, crops and soils under natural vegetation. Out of total global $\mathrm{NH}_{3}$ emissions, about $50 \%$ is contributed from Asia (Bouwman et al., 1997). Other environmental sources of ammonia include industrial emissions and coal gasification.

In India, reactive nitrogen measurements have not been attempted extensively. This study has been carried out to measure $\mathrm{NH}_{3}$ and $\mathrm{NH}_{4}^{+}$concentration at an urban site in Delhi, with an emphasis given to quantifying and explaining differences in the portioning between the particulate and gaseous fractions. 


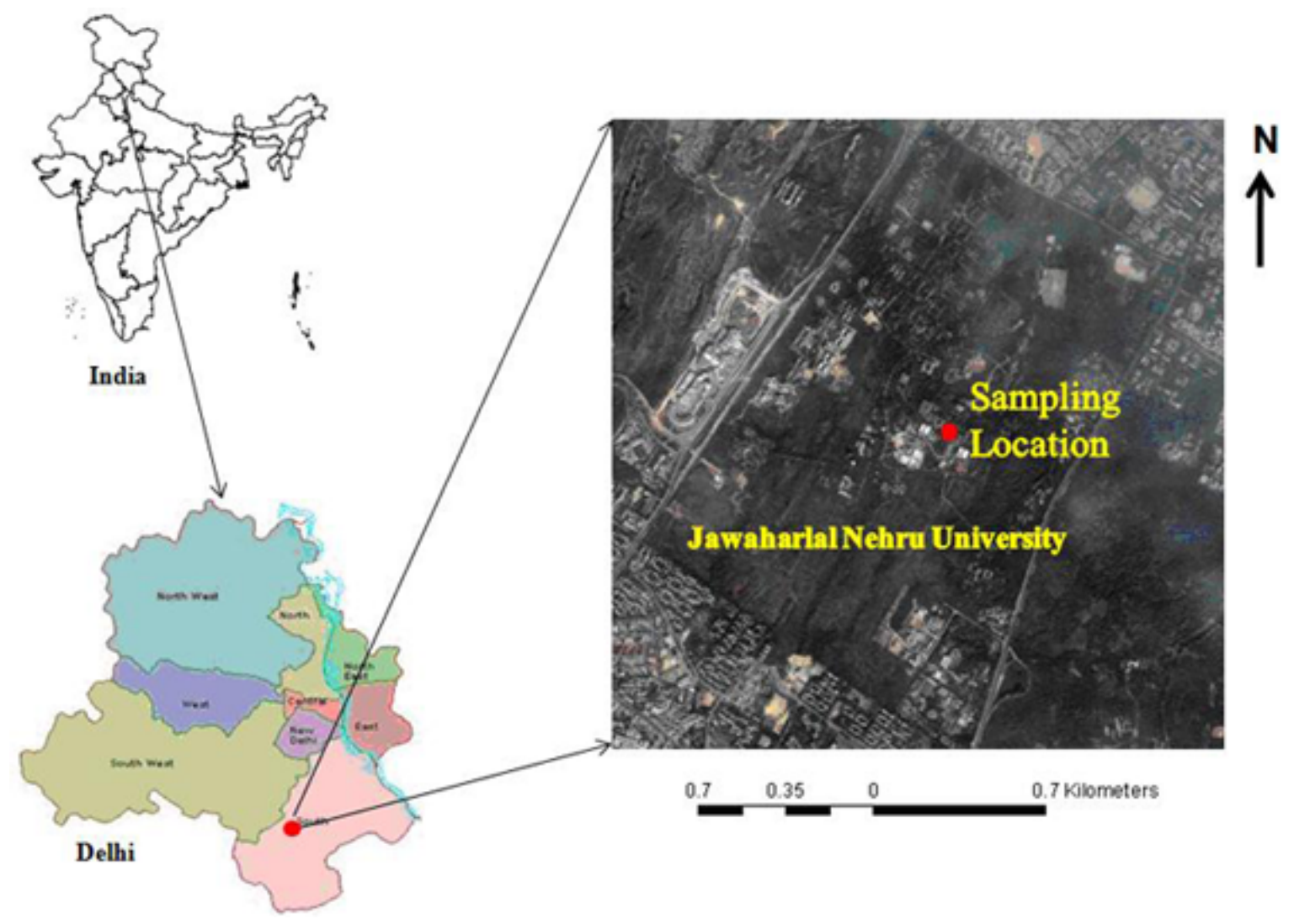

Fig. 1. Map showing sampling site and surroundings.

\section{Methodology}

\subsection{Sampling site}

Sampling was carried out in Delhi. The sampling site was located at the building of the School of Environmental Science (SES), Jawaharlal Nehru University, and New Delhi. The JNU campus lies extremely south of Delhi, (latitude $28^{\circ} 31^{\prime} 30^{\prime \prime}-28^{\circ} 33^{\prime} 30^{\prime \prime} \mathrm{N}$ and longitude $77^{\circ} 9^{\prime}-77^{\circ} 11^{\prime} \mathrm{E}$ ) near a small forest area of around 400 ha, which lies 500, 700, 1500 and $1100 \mathrm{~m}$ to the $\mathrm{N}, \mathrm{E}, \mathrm{S}$, and $\mathrm{W}$, directions, respectively. The air was sampled from the top floor of the SES building by extending tubing through a window (height $\sim 15 \mathrm{~m}$ ). The campus is located away from any industrial activities. The nearest two busy roads run north-south, $1 \mathrm{~km}$ east and $1 \mathrm{~km}$ west to the site, respectively. The traffic density of these roads is of the order of $10^{6}$ vehicles per day. On the JNU campus, no major air pollution sources exist except vehicles like cars and bikes used by the students, faculty, visitors and the kitchens of various cafeterias existing in different hostels and buildings. It is likely that suspended particulate matter contamination may occur from the construction work going on near the School of Environmental Science. Flying planes also pass through the site to the south to land at IGI airport, which is around $5 \mathrm{~km}$ away to the west of the sampling site. Figure 1 shows the location of sampling site.

\subsection{Sample collection}

Gaseous $\mathrm{NH}_{3}$ and aerosol samples were collected using a low volume pump (flow rate $=1 \mathrm{LPM}$ ). Air was sucked directly through an open-face filter pack without using sampling inlet tubing. Filter pack was connected to the impinger through silicon tubing. Samples were collected between April 2010 and July 2011. In the months of April and November 2010, $\mathrm{NH}_{3}$ was collected by passing air through $25 \mathrm{mM} \mathrm{H}_{2} \mathrm{SO}_{4}$ $(20 \mathrm{~mL})$ in a standard impinger for $5 \mathrm{~h}$. The particulate $\mathrm{NH}_{4}^{+}$ was collected on Whatman 41 cellulose filters $(\mathrm{dia}=47 \mathrm{~mm})$ which was placed upstream of the impinger. On an average, the collection efficiency of impinger technique for $\mathrm{NH}_{3}$ was estimated at $83 \%$. Collection efficiency of the method was checked by using two impingers in series and it was estimated only for the $\mathrm{NH}_{3}$ by using the following formula:

Collection efficiency $=\eta_{2}^{*} 100 /\left(\eta_{1}+\eta_{2}\right)$,

where ' $\eta_{1}$ and ' $\eta_{2}$ are the values of optical density in impingers 1 and 2 , respectively. 


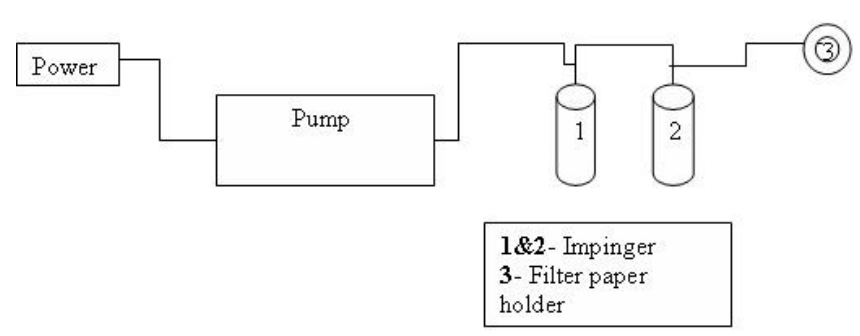

Fig. 2. Flow diagram of sampling assembly.

Such correction did not affect aerosol concentrations. These calculations indicated that without using efficiency correction, aerosol fraction is overestimated by $\sim 2 \%$.

In total, 91 samples of gaseous $\mathrm{NH}_{3}$ and 72 samples of particulate $\mathrm{NH}_{4}^{+}$were collected out of which 80 and 60 samples were found useful for $\mathrm{NH}_{3}$ and $\mathrm{NH}_{4}$, respectively. During the day, sampling was performed between 08:00 a.m. and 01:00 p.m., and at night between 06:00 p.m. and 11:00 p.m. Each aerosol sample represented the duration of two gaseous $\mathrm{NH}_{3}$ samples collected during day and night. In order to collect samples with better efficiency, from May-July 2011, gaseous samples were collected using mist chambers instead of impingers at similar flow rate. This technique has been found more useful for $\mathrm{NH}_{3}$ collection (efficiency > 99\%). Particulate $\mathrm{NH}_{4}^{+}$was extracted immediately by shaking with deionized water $(10 \mathrm{~mL})$ for $30 \mathrm{~min}$ in a ultrasonic bath.

\section{Sampling train setup}

The sampling unit consisted of two standard impingers, one pump, flow meter, connecting tubes (Fig. 2). The filter holder was exposed to outside air for the collection of aerosols. Impinger No. 2 was used to find out the efficiency of collection.

\subsection{Analysis}

Samples were analyzed immediately after the collection. Both gaseous $\mathrm{NH}_{3}$ and particulate $\mathrm{NH}_{4}^{+}$were determined colorimetrically with the help of UV-Vis spectrophotometer (Perkin Elmer, USA) using the indophenol blue method. In this method, a blue indophenol dye is formed in the sodium pentacyanonitrosylferrate catalyzed phenol-hypochlorite reaction with $\mathrm{NH}_{3}$ in alkaline solution. The color intensity is directly proportional to the $\mathrm{NH}_{4}^{+}$present. The intensity of resultant $\mathrm{NH}_{4}^{+}$complex was determined at $630 \mathrm{~nm}$. It is worth mentioning here that other common gaseous pollutants such as $\mathrm{SO}_{2}, \mathrm{O}_{3}, \mathrm{NO}_{2}$ at their normal atmospheric levels do not interfere with this method. However, other reduced N compounds such as amines have cross sensitivity during color development.

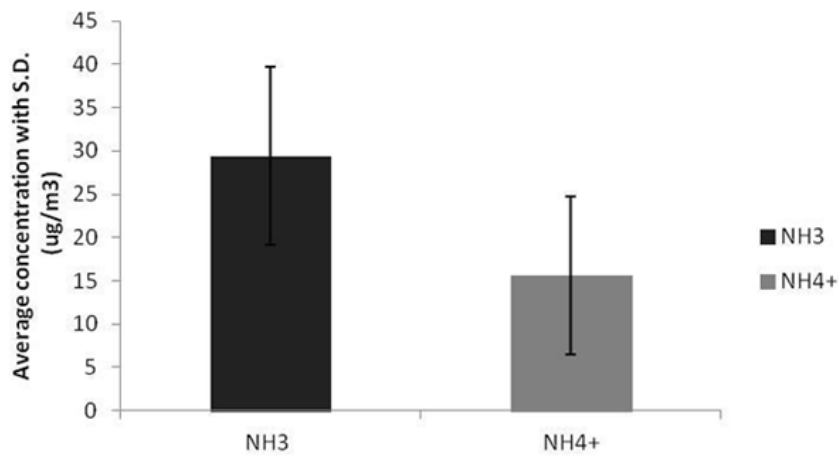

Fig. 3. Average concentration of gaseous $\mathrm{NH}_{3}$ and particulate $\mathrm{NH}_{4}^{+}$. Error bar shows standard deviation (S.D.) $\left(n=91\right.$ for $\mathrm{NH}_{3}$ and $n=$ 72 for the $\mathrm{NH}_{4}^{+}$).

\section{Results and discussion}

\subsection{Average variation of $\mathrm{NH}_{3}$ and $\mathrm{NH}_{4}^{+}$}

Figure 3 shows the average concentrations and standard deviation of gaseous $\mathrm{NH}_{3}$ and particulate $\mathrm{NH}_{4}^{+}$. Gaseous $\mathrm{NH}_{3}$ varied from 9.8 to $63.8 \mu \mathrm{g} \mathrm{m}^{-3}$ with an average of $29.4 \mu \mathrm{g} \mathrm{m}^{-3}$. Particulate $\mathrm{NH}_{4}^{+}$varied from 1.4 to $39.4 \mu \mathrm{g} \mathrm{m}^{-3}$ with an average of $15.56 \mu \mathrm{g} \mathrm{m}^{-3}$. Values of gaseous $\mathrm{NH}_{3}$ in the similar order of magnitude have been reported two decades back by Kapoor et al. (1992) at Delhi $\left(32.6 \mu \mathrm{g} \mathrm{m}^{-3}\right)$ and Zutshi et al. (1970) at Mumbai $\left(35 \mu \mathrm{g} \mathrm{m}^{-3}\right)$. Both $\mathrm{NH}_{3}$ and $\mathrm{NH}_{4}^{+}$varied, covering large ranges of concentration, which can be attributed to the various activities taking place in the surroundings, vegetation cover, land use patterns and meteorological factors. The concentration of $\mathrm{NH}_{3}$ depends mainly on source strength, atmospheric chemistry and temperature and humidity etc. Bowman et al. (1997) and Goebes et al. (2003) have reported higher emission of $\mathrm{NH}_{3}$ due to fertilizer application during spring and fall because high temperature increases volatilization of $\mathrm{NH}_{3}$. Volatilization is temperature-dependent and varies significantly over day and seasons (Skjoth et al., 2004). In tropical regions, the effect of high temperatures can enhance the volatilization, thus contributing to higher amounts of $\mathrm{NH}_{3}$. This might be one of the possible reasons for higher $\mathrm{NH}_{3}$ concentrations at Indian sites (Kulshrestha et al., 2009; Singh et al., 2001). As compared to $\mathrm{NH}_{4}^{+}$, higher $\mathrm{NH}_{3}$ concentrations at Indian sites might be due to large contribution from $\mathrm{NH}_{3}$ sources and relatively slow scavenging and $\mathrm{NH}_{4}^{+}$conversion processes.

It is worth mentioning here that $\mathrm{NH}_{3}$ measurements have uncertainty due to various reasons. The use of Whatman 41 cellulose prefilter for $\mathrm{NH}_{3}$ collection raises the possibility of $\mathrm{NH}_{3}$ capture on the prefilter during humid conditions. However, in the United Kingdom, such interaction has not been found significant (Sutton et al., 1993) but under Indian conditions, such an effect may be more relevant and needs to be investigated. In addition, the uncertainty in $\mathrm{NH}_{3}$ estimation due 


\section{How alkaline dust is responsible for higher $\mathrm{NH}_{3}$}
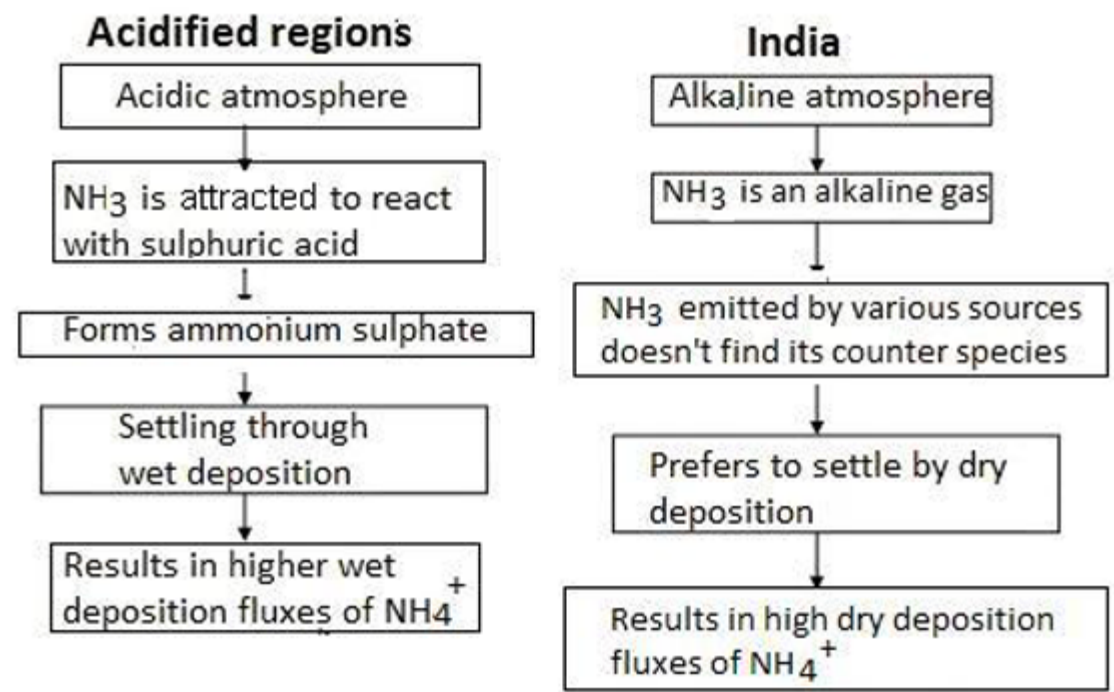

Fig. 4. Flow chart showing reason for higher $\mathrm{NH}_{3}$ in Indian region.

Table 1. Comparison of concentrations of gaseous ammonia with other studies.

\begin{tabular}{llrrl}
\hline Site & $\begin{array}{l}\text { Characteristics } \\
\text { of site }\end{array}$ & $\begin{array}{r}\text { Concentration } \\
\left(\mu \mathrm{g} \mathrm{m}^{-3}\right)\end{array}$ & $\mathrm{NH}_{4} / \mathrm{NH}_{\mathrm{X}}(\%)$ & Reference \\
\hline Mumbai (Trombay) & Urban & 35.0 & 8.8 & Zutshi et al. (1970) \\
Yokahama & Urban & 5.3 & 30 & Yamamoto et al. (1988) \\
Delhi & Urban & 32.6 & - & Kapoor et al. (1992) \\
Pune & Urban & 2.0 & - & Khemani et al. (1987) \\
Beijing & Urban & 22.26 & - & Ianniello et al. (2010) \\
Agra & Semi Urban & 10.2 & 18.8 & Singh et al. (2001) \\
\hline Abbeville, LA, US & Rural & 0.07 & - & Cadle et al. (1982) \\
Richpur & Rural & 0.9 & - & Khemani et al. (1987) \\
Sinhagad (Rural) & Rural & 0.6 & - & Khemani et al. (1987) \\
\hline Europe & Miscellaneous & $0.06-11$ & - & Sutton et al. (2001a) \\
\hline Pacific ocean & Marine & 0.004 & - & Quinn et al. (1988) \\
Arabian sea & Marine & 1.6 & - & Khemani et al. (1987) \\
Bay of Bengal & Marine & 1.9 & - & Khemani et al. (1987) \\
\hline Delhi (Urban) & & 29.4 & Present study \\
\hline
\end{tabular}

to the impinger technique can be reduced by using denuder technique where the $\mathrm{NH}_{3}$ is trapped first and the remainder is captured on a filter (Sutton et al., 2001b).

\subsection{Comparison of Gaseous $\mathrm{NH}_{3}$ concentration with other studies}

Table 1 gives comparison of $\mathrm{NH}_{3}$ reported by various workers at different sites worldwide. Interestingly, there are sufficient data available for $\mathrm{NH}_{4}^{+}$in rainwater at remote ru- ral, urban, semiurban and marine sites worldwide (Lenhard and Gravenhorst, 1980; Likens et al., 1987; Galloway et al., 1987; Galloway, 1988; Khemani et al., 1989; Possanzini et al., 1988; Tuncel and Unger, 1996; Parashar et al., 1996; Khare et al., 1996; Kulshrestha et al., 2005; Satyanarayana et al., 2010). But very few studies report $\mathrm{NH}_{3}$ and $\mathrm{NH}_{4}^{+}$ in air (Table 1). The comparison shows that at most Indian sites, gaseous $\mathrm{NH}_{3}$ concentrations are reported higher than at other sites. Within India, urban sites show higher gaseous $\mathrm{NH}_{3}$ than that of rural sites. Higher concentration at urban 


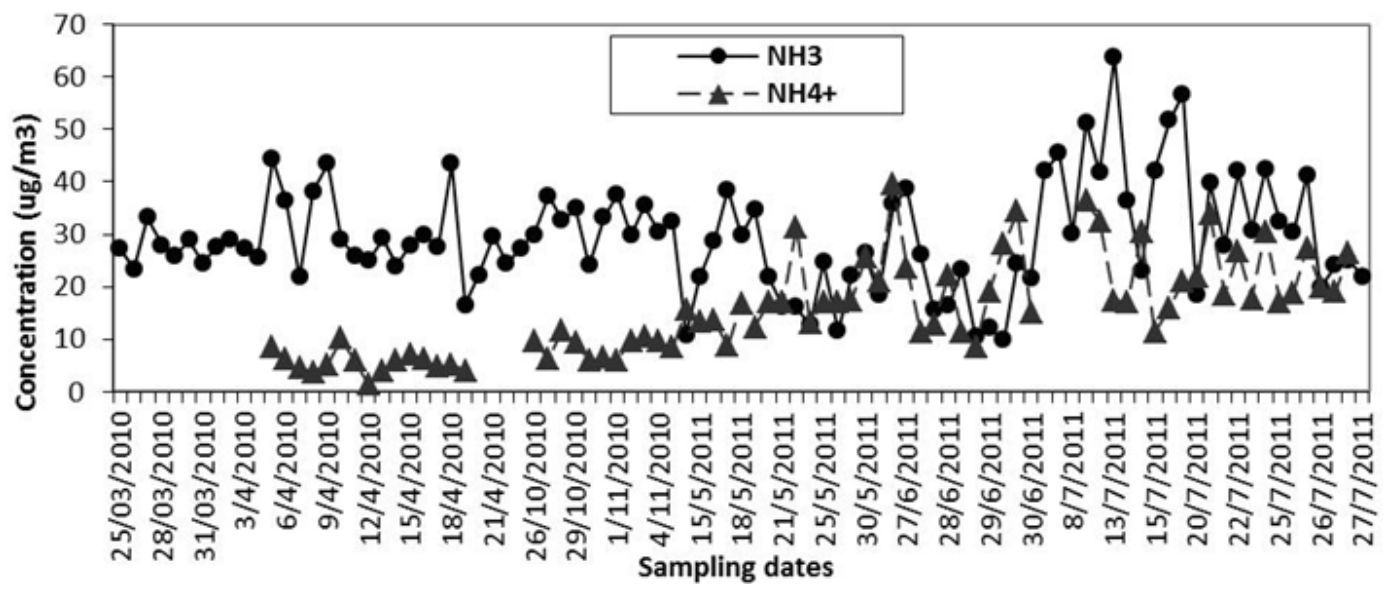

Fig. 5a. Full time series with all the day measurements for both $\mathrm{NH}_{3}$ and $\mathrm{NH}_{4}^{+}$.

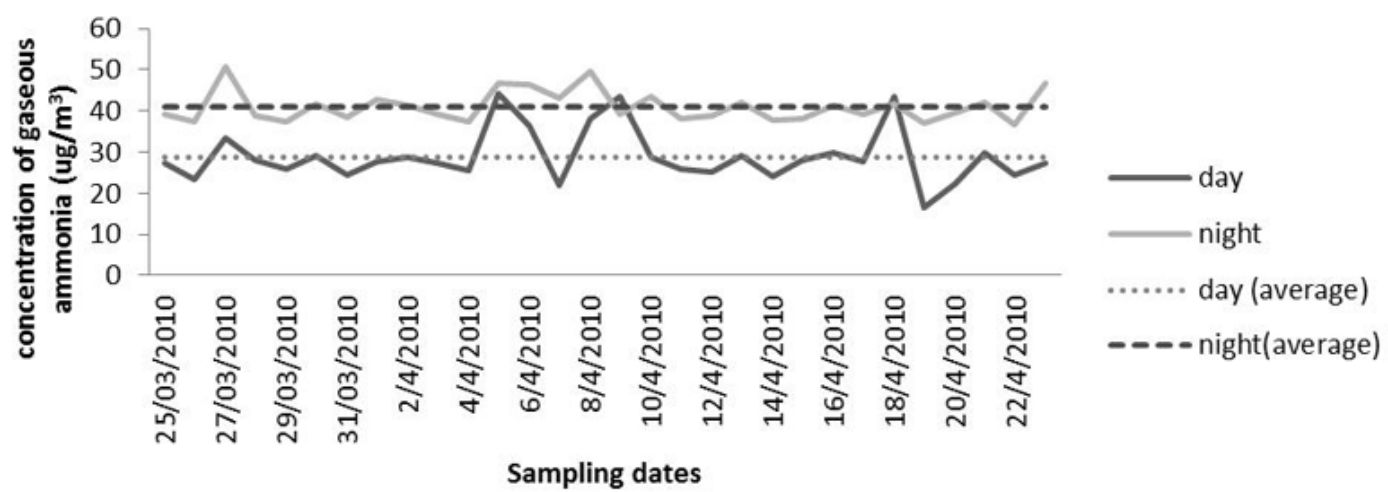

Fig. 5b. Average diurnal variation of $\mathrm{NH}_{3}$.

sites may be due to increased population density, various activities and poor sanitation arrangements. Another possible reason of higher gaseous $\mathrm{NH}_{3}$ in India is due to strong source contribution and inefficient wet deposition. In addition, alkaline atmospheric conditions due to soil-derived particles do not encourage $\mathrm{NH}_{3}$ (an alkaline gas) to get adsorbed onto the particles in air. Figure 4 shows how alkaline soil dust is responsible for higher $\mathrm{NH}_{3}$ concentrations in India. The soil dust, which is rich in $\mathrm{CaCO}_{3}$, is mainly contributed by resuspension of soils from the nearby Thar desert and open agricultural fields. The high dust content in the atmosphere is a typical feature of Indian continental region (Kulshrestha et al., 2005).

\subsection{Diurnal variation}

Full time series of all daytime measurements of $\mathrm{NH}_{3}$ and $\mathrm{NH}_{4}^{+}$are shown in Fig. 5a. Figure 5b shows the variation of gaseous ammonia in day and night. It is very clear that the nighttime concentrations are higher than the daytime. The daytime concentrations of $\mathrm{NH}_{3}$ varied from 16.6 to $44.3 \mu \mathrm{g} \mathrm{m}^{-3}$ with an average value of $28.9 \mu \mathrm{g} \mathrm{m}^{-3}$, whereas the nighttime concentrations varied from 36.5 to $50.8 \mu \mathrm{g} \mathrm{m}^{-3}$ with an average value of $41.07 \mu \mathrm{g} \mathrm{m}^{-3}$. The high $\mathrm{NH}_{3}$ concentrations during nighttime are probably due to stable atmospheric conditions. Burkhardt et al. (1998) have also reported higher concentrations of $\mathrm{NH}_{3}$ during nighttime due to stable atmospheric conditions, which results in the trapping of gaseous $\mathrm{NH}_{3}$ near ground level. Similar observations have been reported by Cadle et al. (1982) and Singh et al. (2001).

\subsection{Variation during pre-monsoon, monsoon and post-monsoon}

Figure 6 shows that the gaseous $\mathrm{NH}_{3}$ concentrations are the highest during monsoon season (July-September), a period of higher rainfall, whereas it is observed to be the lowest in the samples collected during pre-monsoon. The average concentration of gaseous $\mathrm{NH}_{3}$ during pre-monsoon (March-June) was $26.47 \mu \mathrm{g} \mathrm{m}^{-3}$, whereas in the monsoon period it was on an average $33.15 \mu \mathrm{g} \mathrm{m}^{-3}$. In post-monsoon (October-November), the average value of gaseous $\mathrm{NH}_{3}$ was $32.5 \mu \mathrm{g} \mathrm{m}^{-3}$. The highest concentration of $\mathrm{NH}_{3}$ during monsoon season may be due to decay and decomposition 


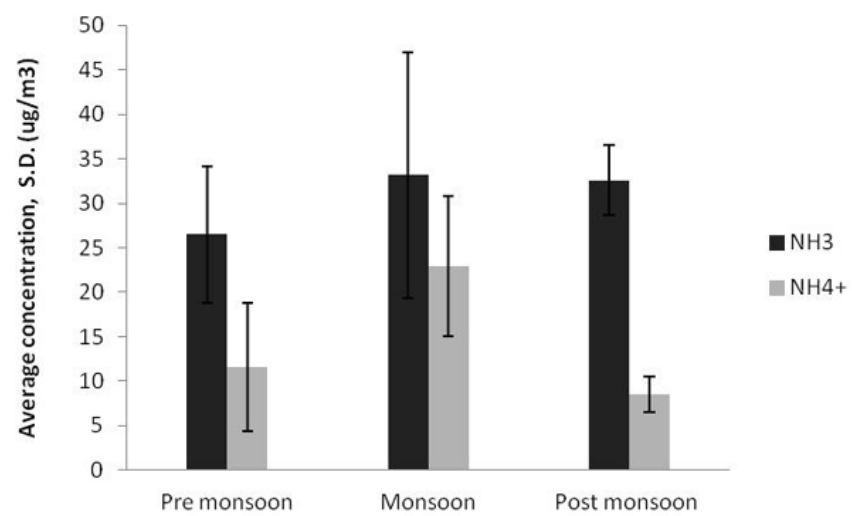

Fig. 6. Average concentration and standard deviation (S.D.) of gaseous $\mathrm{NH}_{3}$ and particulate $\mathrm{NH}_{4}^{+}$during different seasons. $(n=50$ for $\mathrm{NH}_{3}$ and $n=33$ for $\mathrm{NH}_{4}^{+}$in pre-monsoon, $n=30$ for $\mathrm{NH}_{3}$ and $n=28$ for $\mathrm{NH}_{4}^{+}$in monsoon whereas $n=11$ for $\mathrm{NH}_{3}$ and $n=11$ for $\mathrm{NH}_{4}^{+}$in post-monsoon).

of plants and other biogenic material under wet conditions which emit $\mathrm{NH}_{3}$. In addition, seasonality in agricultural source activity, like growing seasons and timing of manure application to fields, can also influence the seasonal concentration of $\mathrm{NH}_{3}$. However, this influence may be more effective in rural areas as compared to the present site.

\subsection{Estimation of percent fraction of gaseous and particulate ammonia}

Based on average values of gaseous ammonia and particulate ammonia, percentage fraction was calculated for $\mathrm{N}-\mathrm{NH}_{3}$ and $\mathrm{N}-\mathrm{NH}_{4}^{+}$as follows:

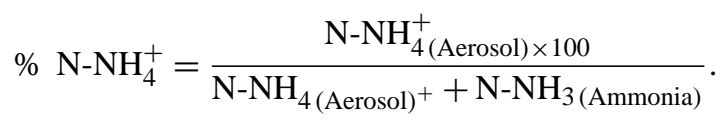

The results show that particulate ammonia was always lower than the gaseous ammonia in all the seasons. The percent fraction of particulate $\mathrm{N}-\mathrm{NH}_{4}^{+}$was $33.3 \%$ of total $\mathrm{N}(\mathrm{N}$ $\left.\mathrm{NH}_{4}^{+}+<\mathrm{N}-\mathrm{NH}_{3}\right)$. The percent fraction of particulate ammonia was most noticeable during monsoon season, followed by pre-monsoon and post-monsoon. The highest $\mathrm{N}-\mathrm{NH}_{4}^{+}$ during monsoon may be due to higher relative humidity, which results in faster $\mathrm{NH}_{3}-\mathrm{NH}_{4}^{+}$conversion.

\section{Summary}

Seasonal variation data showed that gaseous $\mathrm{NH}_{3}$ concentrations were the highest during the monsoon period, which might be due to decay and decomposition of plants and other biogenic material under wet conditions which emit $\mathrm{NH}_{3}$. It might also be due to seasonality in agriculture sources and manure application, which might have higher influence at rural sites as compared to the present urban site. It was noticed that particulate $\mathrm{NH}_{4}^{+}$was always lower than the gaseous $\mathrm{NH}_{3}$ in all the seasons. The percent fraction of particulate $\mathrm{N}-$ $\mathrm{NH}_{4}^{+}$was most noticeable during monsoon season due to increased humidity levels. Gaseous $\mathrm{NH}_{3}$ levels were recorded to be higher during nighttime than daytime, which is consistent with higher atmospheric stability during nighttime and an associated reduced dispersion of this gas, which typically emitted from low-level sources.

Acknowledgement. Authors are thankful to DST and JNU for providing financial assistance through PURSE CBF. Help of CSIR is also acknowledged for awarding Junior Research Fellowship to Saumya Singh.

Edited by: M. Sutton

\section{References}

Bouwman, A. F., Lee, D. S., Asman, W. A. H., Dentener, F. J., van der Hoek, K. W., and Olivier, J. G. J.: A global high-resolution emission inventory for ammonia, Global Biogeochem. Cy., 11, 561-587, 1997.

Burkhardt, J., Sutton, M. A., Milford, C., Storeton-West, R. L., and Fowler, D.: Ammonia concentrations at a site in Southern Scotland from 2 years of continuous measurements, Atmos. Environ., 32, 325-331, 1998.

Cadle, S. H., Countessand, R. J., and Kelley, N. A.: Nitric acid and ammonia in urban and rural locations, Atmos. Environ., 16, 2501-2506, 1982.

Galloway, J. N.: Effects of acid deposition on tropical aquatic ecosystems, in: Acidification in Tropical Countries, edited by: Rodhe, H. and Herrera, R., SCOPE 36, Wiley, New York, 141$166,1988$.

Galloway, J. N., Zhao, D. W., Xiong, J., and Likens, G. E.: Acid rain: China, US and a remote area, Science, 230, 1559-1562, 1987.

Goebes, M. D., Strader, R., and Davidson, C.: An ammonia emission inventory For fertilizer application in the United States, Atmos. Environ., 37, 2539-2550, 2003.

Ianniello, A., Spataro, F., Esposito, G., Allegrini, I., Rantica, E., Ancora, M. P., Hu, M., and Zhu, T.: Occurrence of gas phase ammonia in the area of Beijing (China), Atmos. Chem. Phys., 10, 9487-9503, doi:10.5194/acp-10-9487-2010, 2010.

Jougebreur, A. A. and Voorburg, J. H.: The role of ammonia in acidification. Perpectives for the prevention and reductions of emissions from livestock operarations, Stud. Environ. Sci., 50, 55-64, 1992.

Kapoor, R. K., Singh, G., and Tiwari, S.: Ammonia Concentration Vis-à-vis Meteorological Conditions at Delhi, India, Atmos. Res., 28, 1-9, 1992.

Khare, P., Kapoor, S., Kulshrestha, U. C., Saxena, A., Kumar, N. K., Maharaj Kumari, M., and Srivastava, S. S.: Variation in ionic composition of precipitation collected by sequential sampling, Environ. Tech., 17, 637-642, 1996. 
Khemani, L. T., Momin, G. A., Naik, M. S., Rao, P. S. P., Kumar, R., and Ramana Murty, B. V.: Influence of alkaline particulate on $\mathrm{pH}$ of cloud and rain water in India, Atmos. Environ., 21, 1137$1145,1987$.

Khemani, L. T., Momin, G. A., Naik, M. S., Rao, P. S. P., Safai, P. D., Singh, G., and Kapoor, R. K.: Spread of acid rain over India, Atmos. Environ., 23, 757-762, 1989.

Kulshrestha, U. C., Granat, L., Engardt, M., and Rodhe, H.: Review of precipitation monitoring studies in India - a search for regional patterns, Atmos. Environ., 39, 4419-4435, 2005.

Kulshrestha, U. C., Kulshrestha, M. J. Satyanarayana, J., Kulshrestha, M. J., and Reddy, L. A. K.: Atmospheric deposition of reactive nitrogen in India, in: Nitrogen deposition and critical loads Proceedings of an International Workshop, edited by: Sutton, M. A., Mason, K., Sheppard, L. J., Sverdrup, H., Haueber, R., and Hicks, W. K., Springer Edinburgh, in press, 2009.

Lenhard, V. and Gravenhorst, G.: Evaluation of ammonia of fluxes into the free atmosphere over Western Germany, Tellus, 328, 48$55,1980$.

Likens, G. E., Keene, W. C., Miller, J. M., and Galloway, J. N.: Chemistry of precipitation from a remote, terrestrial site, Australia, J. Geophys. Res., 92, 13299-13314, doi:10.1029/JD092iD11p13299, 1987.

Parashar, D. C., Granat, L., Kulshreshtha, U. C., Pillai, A. G., Naik, M. S., Momin, G. A., Rao, P. S. P., Safai, P. D., Khemani, L. T., Naqavi, S. W. A., Narverkar, P. V., Thapa, K. B., and Rodhe, H.: Report CM-90, Department of meteorology Stockholm University International meteorological Institute in Stockholm, Sweden, 1996.

Possanzini, M., Buttini, P., and Dipalo, V.: Characterization of a rural area in terms of dry and wet deposition, The Sci. Total Environ., 74, 111-120, 1988.

Quinn, P. K., Charlson, R. J., and Bates, T. S.: Simultaneous observations of ammonia in the atmosphere and ocean, Nature, 335, 336-338, 1988.

Satyanarayana, J., Reddy, L. A. K., Kulshrestha, M. J., Rao, R. N., and Kulshrestha, U. C.: Chemical composition of rain water and influence of airmass trajectories at a rural site in an ecological sensitive area of Western Ghats (India), J. Atmos. Chem., 66, 101-116, doi:10.1007/s10874-011-9193-2, 2010.
Singh, S. P., Satsangi,G. S., Khare, P., Lakhani, A., Maharaj Kumari, K., and Srivastava, S. S.: Multiphase Measurement of Atmospheric Ammonia, Chemosphere-Global Change Sci., 3, 107116, 2001.

Skjøth, C. A., Hertel, O., Gyldenkærne, S., and Ellermann, T.: Implementing a dynamical ammonia emission parameterization in the large-scale air pollution model ACDEP, J. Geophys. Res., 109, D06306, doi:10.1029/2003JD003895, 2004.

Sutton, M. A., Lee, D. S., Dollard, G. A., and Fowler, D.: Introduction atmospheric ammonia: emission, deposition and environmental impacts, Atmos. Environ., 32, 269-271, 1998.

Sutton, M. A., Fowler, D., and Moncrieff, J. B.: The exchange of atmospheric ammonia with vegetated surfaces. I: Unfertilized vegetation, Q. J. Roy. Meteorol. Soci., 119, 1023-1045, 1993.

Sutton, M. A., Tang, Y. A., Dragosits, U., Fournier, N., Dore, A. J., Smith, R. I., Weston, K. J., and Fowler, D.: A Spatial Analysis of Atmospheric Ammonia and Ammonium in the UK, The Scientific World, 1, 275-286, 2001a.

Sutton, M. A., Tang, Y. S., Miners, B., and Fowler, D.: A New Diffusion Denuder System for Long-Term, Regional Monitoring of Atmospheric Ammonia and Ammonium, Water Air Soil Pollut., 1, 145-156, 2001b.

Sutton M. A., Reis S., and Baker S. M. H.: Atmospheric Ammonia: Detecting emission changes and environmental impacts, Springer, 464 pp., 2009.

Tuncel, S. G. and Unger, S.: Rain water chemistry in Ankara Turkey, Atmos. Environ., 30, 2721-2727, 1996.

Yamamoto, N., Kabeya, N., Onodera, M., Takahahi, S., Komori, Y., Nakazuka, E., and Shirai, T.: Seasonal variation of atmospheric ammonia and particulate ammonium concentrations in the urban atmosphere of Yokohama over a 5-year period, Atmos. Environ., 22, 2621-2623, 1988.

Zutshi, P. K., Sequeira, R., Mahadevan, T. N., and Banerjee, T.: Environmental concentrations of some of the major inorganic pollutants at the BARC site, Trombay, Indian J. Meteorol. Geophys., 21, 473-478, 1970. 